\title{
Perceived violations of reward delivery obligations in reward-based crowdfunding: an integrated theoretical framework
}

Perceptions in reward-based crowdfunding

\author{
Anthony Macari and Grace Chun Guo \\ Sacred Heart University, Fairfield, Connecticut, USA
}

\begin{abstract}
Purpose - This conceptual paper focuses on a common observation in the implementation stage of rewardbased crowdfunding (RBC) - entrepreneurs' failures and delays in delivery of rewards to investors, which, in turn, may be perceived as violations of reward delivery obligations.

Design/methodology/approach - Drawing on entrepreneurial personality theory and psychological contract theory, this paper develops propositions and identifies factors related to both entrepreneurs (overconfidence and narcissism) and factors related to investors (types of motivators and psychological contracts) that may explain the perceived violations of reward delivery obligations. Implications for theory and practice are also discussed.

Findings - The theoretical analysis, by wielding two independently developed literatures, has demonstrated that it is important to investigate factors that are related to both investors and entrepreneurs in understanding issues and challenges at different stages of the RBC model. The authors believe that the current analysis provides an integrated understanding and a solid foundation for researchers to further examine these issues by empirically testing these propositions.

Originality/value - The authors examined two previously understudied psychological factors in the context of RBC - entrepreneurial traits, mainly overconfidence and narcissism, and the type of psychological contracts formed between investors and entrepreneurs, both of which, according to McKenny et al. (2017), need greater attention from researchers studying crowdfunding.
\end{abstract}

Keywords Crowdfunding platforms, Entrepreneurial personality, Failure and delay in reward delivery, Investor motivators, Legal issues, Narcissism, Overconfidence, Psychological contracts,

Reward-based crowdfunding, Perceived violation of reward delivery obligation

Paper type Conceptual paper

\section{Introduction}

Crowdfunding has emerged as a significant and growing source of capital for entrepreneurs who may not have access to capital markets via banks, venture capital or other traditional sources (Allison et al., 2015; McKenny et al., 2017; Short et al., 2017). Crowdfunding refers to an entrepreneur's direct solicitation, usually through Internet platforms, such as Kickstarter or Indiegogo, to a large number of individuals (i.e. the crowd) who may or may not have historic or personal ties to the entrepreneur (Belleflamme et al., 2014). Many online platforms have specific niches such as the creative arts, new consumer products and even litigation funding.

There are four main forms of crowdfunding: donations-based (Kappel, 2009), rewardsbased (Bellefamme et al., 2014; Colombo et al., 2015; Mollick, 2014), debt-based (Zhang and Liu, 2012) and equity-based (Ahlers et al., 2015). These forms differ in terms of the investment and

(C) Anthony Macari and Grace Chun Guo. Published in New England Journal of Entrepreneurship. Published by Emerald Publishing Limited. This article is published under the Creative Commons Attribution (CCBY 4.0) license. Anyone may reproduce, distribute, translate and create derivative works of this article (for both commercial and non-commercial purposes), subject to full attribution to the original publication and authors. The full terms of this license may be seen at http://creativecommons. org/licences/by/4.0/legalcode

Received 16 August 2019 Revised 26 June 2020 29 December 2020 Accepted 1 April 2021

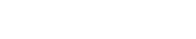

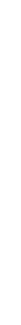


NEJE

24,1

the expectations of investors. Donations-based crowdfunding is dedicated solely to charitable causes and follows a patronage model, placing funders in the position of philanthropists, who expect no direct return for their donations (Mollick, 2014). Debt-based crowdfunding resembles a more traditional lending model, which allows investors to make microloans to entrepreneurs (Short et al., 2017). In this model, entrepreneurs usually pay investors with interest and principal. Equity-based crowdfunding was made possible since the passage of the Jumpstart Our Business Startups (JOBS) Act in 2012. Equity-based crowdfunding allows investors to provide funds in return for an equity stake in the new venture, which entitles them to a share of the profits or capital gains. Given the nature of the investment and the fact that the securities and exchange commission (SEC) will have oversight over equity-based crowdfunding, equity-based crowdfunding platforms are often highly structured and have detailed requirements for funding (Agrawal et al., 2014). Finally, in rewards-based crowdfunding (RBC), investors receive perks such as advance versions of a funded product rather than receiving a financial return on their contributions (Agrawal et al., 2014)

Among these four, reward-based crowdfunding is the most prevalent (based on the number of platforms available) (Mollick, 2014) due to the relative ease with which an investor can make an investment and the limited amount of disclosure required by an entrepreneur. However, prior research (e.g. Moores, 2015; Ganatra, 2016) has shown that unlike equity and debt-based crowdfunding, RBC transactions lack detailed legal contracts and extensive regulation and, hence, are subject to violations of the terms of use (TOU), in particular, the requirement to "complete the project and fulfill each reward" (Kickstarter website). Although failures or delays in reward delivery can potentially have a serious impact on a large number of investors, fraud is estimated to account for less than $1 \%$ of all funded projects (Cumming et al., 2016). This leaves the remaining unintentional failures and delays open to individual interpretation and subjective evaluations as to why they occur so frequently.

In this paper, we focus on the implementation stage of the RBC model and build an integrated theoretical framework to identify factors that may explain the perceived violation of reward delivery obligations. We believe that $\mathrm{RBC}$ establishes a contractual relationship between the entrepreneur (the creator) and the investor (the backer). On the one hand, we argue that entrepreneurial personality theory may explain how traits, such as overconfidence and narcissism, may result in the entrepreneur's overestimation of his or her ability to design, manufacture and deliver the rewards to the investors, hence leading to failures and delays in delivering rewards to investors. On the other hand, drawing on the psychological contract theory (Robinson, 1996; Rousseau, 1995, 2004) and prior research on investor motivators (Mollick, 2014), we argue that investors may form different types of psychological contracts with the entrepreneur (i.e. relational versus transactional) depending on the investors' internal motivators (i.e. intrinsic versus extrinsic). The type of psychological contract, in turn, may be perceived as violation of reward delivery obligations.

Indeed, prior crowdfunding studies have examined factors that contributed to the success of project campaigns in the initial stage of the RBC model. For example, Li et al. (2017) found that when entrepreneurs displayed entrepreneurial passion in the introductory video for a crowdfunding project, it increased viewers' experienced enthusiasm about the project, which then prompted them to contribute financially and to share campaign information via social media channels. Similarly, Davis et al. (2017) examined investors' perceptions and found that the indirect effect of product creativity is contingent on the extent to which funders perceive an entrepreneur to be passionate. Moreover, Ciuchta et al. (2018) examined the effect of the entrepreneur's coachability on a potential investor's willingness to invest. Our analysis extends these prior studies by examining failures and challenges in the implementation stage after the entrepreneurs have successfully raised funds and met their funding goals. Although recent research has identified reasons behind the observed high percentage of delays in 
delivering rewards to investors, there is a lack of a theoretical explanation of why such failures and delays commonly occur and whether these failures and delays are perceived as violations of reward delivery obligations, hence the focus of our investigation.

In the rest of the paper, we review the literature on the $\mathrm{RBC}$ model as a contractual relationship and discuss legal issues associated with the $\mathrm{RBC}$ model. We also review entrepreneurial personality theory and psychological contract theory to develop a conceptual framework with propositions about factors that may result in failures and delays in reward delivery as well as variations in perceived violations of reward delivery obligations. Implications for theory and practice are also discussed.

\section{Literature review}

Reward-based crowdfunding $(R B C)$ model as a contractual relationship

$\mathrm{RBC}$ establishes a simple contractual relationship between the entrepreneur (the creator) and the investor (the backer). Investors are provided a list of possible rewards based on the amount of funding that they provide, and the entrepreneur is obligated to deliver those rewards once funds are accepted. The norm for most RBC projects is that investors want rewards in the form of product, similar to a presell for a new consumer product. For example, Chippo Golf had an initial funding goal of $\$ 12,000$ but instead raised $\$ 233,349$ due to the fact that 1,230 individuals contributed an average of $\$ 189.71$ (Kickstarter website). The rewards available included two beverage-can coolers for a $\$ 10$ pledge, a Chippo T-shirt for $\$ 30$ and the actual product for $\$ 169$ for a single to $\$ 825$ for a 5 pack. Since the average pledge was $\$ 189.71$, this indicates that most funders selected one or more units of the product and that the number of rewards required greatly surpassed the initial expectation.

Currently, most crowdfunding online platforms include terms of service or terms and conditions similar to the Kickstarter TOU. For example, on the Kickstarter website (Section 4), the TOU policy clearly states that a contract exists between the entrepreneur and the investor, and that Kickstarter is not a party to this contract. The TOU is relatively simple and not filled with detailed or complex legal language. The TOU uses terms of art common in many legal contracts, but those terms are open to interpretation. From both a practical and legal standpoint, it defines the entrepreneur's contractual obligation as "the creator must complete the project and fulfill each reward". It also states that "if the creator is unable to complete their project and fulfill rewards, they've failed to live up to the basic obligations of this agreement" (Kickstarter.com/terms-of-use). In the latter case, the steps and deliverables which must be undertaken in order to meet the obligation are usually listed on the online platform. For example, the TOU for Kickstarter (Kickstarter.com/terms-of-use) uses the term "high standard of effort" to describe the entrepreneur's obligation to fulfill each reward, as well as a number of different standards of effort to describe the acceptable remedies when an entrepreneur does not initially fill all the rewards.

In typical contract negotiations, when a contract includes an efforts clause, attorneys usually spend considerable time and client money to define terms like "high standard of effort", "good faith", "reasonable" and "appropriately". Even after all that discussion, litigation over contract terms can still occur. While these terms appear to be very similar, in terms of case law and litigation they can mean dramatically different things depending on the case law in that state, the type of product involved and the specific facts of the case. "Best efforts" means doing everything possible, regardless of whether it makes economic sense or is practical in order to achieve the agreed upon outcome. This is very different from "reasonable best efforts" where the steps taken have to make economic sense from a cost/benefit analysis (Adams, 2004; Scott and Triantis, 2006). Questions such as whether sufficient "due care" or "due diligence" was used during the process in order to substantiate any claims made are often raised during discovery for litigation. Even without an intent to deceive, in legal terms,
Perceptions in reward-based crowdfunding 
NEJE

24,1

the lack of "reasonable due care to ensure the truth of a statement made to induce another party to enter a contract" could amount to negligent misrepresentation (Black's Law Dictionary, 1990).

In the case of $\mathrm{RBC}$, the entrepreneur or the creator is in effect the seller, and the investor or the backer is the buyer. In situations where the entrepreneur was unprepared either in background, training or in having a viable operating plan, especially in regard to spending funds and delivering the rewards, the entrepreneur may encounter failure or delay in delivery of rewards, which may be perceived as a violation of the reward delivery obligation. Indeed, most investors or backers are aware that they are not purchasing a product off the shelf. Entrepreneurs are also required to post a statement on their website called "risks and challenges". Most "risk and challenges" statements include a few simple paragraphs rather than a detailed boilerplate set of risks similar to those at the end of a press release or in the 10-K of a publicly held company. For example, Kickstarter, Section 4 of the TOU states the following:

At the same time, backers must understand that when they back a project, they're helping to create something new-not ordering something that already exists. There may be changes and delays, and there's a chance something could happen that prevents the creator from being able to finish the project as promised.

While a contract exists between the entrepreneur and the investors, it is also clear that it is not a standard retail contract. From a legal perspective, the crowdfunding platforms have made the effort to alert the investors about the potential risks that the product may not be delivered on time or even at all. Investors are also aware that they cannot monitor the day-to-day operation of the entrepreneur and most likely have not done extensive due diligence for their investment in a reward, which averages about $\$ 76$ (Mollick, 2015).

In short, even for those crowdfunding platforms like Kickstarter, which follows the rule of all-or-none, meaning the entrepreneur cannot collect funds until the entire funding goal is reached, control mechanisms or detailed contractual requirements for spending the funds or defining deadlines for acceptable reward delivery are relatively minimal. Prior research (Mollick, 2014) showed that up to 75\% of funded projects were delayed in providing rewards, and failure to deliver the reward at all, including fraud was estimated to be only $9 \%$. Among 47,188 surveyed investors of funded projects in Mollick (2014), failure to deliver ranged from $5 \%$ (never expect to get the rewards) to $14 \%$ (even a single person reports the project as a failure). In addition, the average delay was 2.4-2.7 months, depending on the type of product (Mollick, 2014). While the time required for extensive contract negotiations and debate of legal language is not conducive to the entrepreneurial effort, the process does serve as a form of forced "due diligence" to help educate the entrepreneur in what may be required to deliver the rewards on a timely basis and what the potential risks are. However, entrepreneurs may perceive less risk in such situations, which later can lead to failure and delays in delivering rewards on time to inventors.

\section{Causes of failures and delays in reward delivery in $R B C$}

Given the high level of late or failed rewards delivery, it is important to review prior research on the causes of those failures and delays in RBC. Prior studies identified various causes, mostly entrepreneurs' individual-level factors, including entrepreneurs' inability to estimate costs and plan key variables, lack of experience and capabilities of implementing funded projects or fulfilling the obligations of reward delivery. For example, Schiavone (2017) summarized the causes for delays in delivery of rewards. These causes include cost underestimates (Buff and Alhadeff, 2013), project size in terms of the amount of money pledged and the number of rewards to be delivered (Mollick, 2014), creator inexperience or incompetence (Agrawal et al., 2014; Zheng et al., 2014), project management problems 
(Turan, 2015; Zheng et al., 2014) and project complexity (Zheng et al., 2014). For example, Buff and Alhadeff (2013) did an analysis of 100 successfully funded music projects from Kickstarter. They identified a common mistake made by creators of setting the fundraising goal without accounting for the cost of rewards, platform fees, taxes and contingencies and created a budgeting spreadsheet to assist creators. Agrawal et al. (2014) identified disincentives for funders to invest in projects and addressed the lack of experience that entrepreneurs had in the development of prototypes as well as in building the product and dealing with supplier and logistical issues.

Zheng et al. (2014) conducted a questionnaire study of 114 projects from Demohour.com, a leading RBC platform in China. They found that projects with a higher level of accumulated team experience as well as experience of working together had better results. This study also found that detailed project planning should be encouraged to improve delivery times. In addition, based on a qualitative analysis of nine projects, Schiavone (2017) confirmed that the primary issues were ex ante and ex post incompetence. Ex ante incompetence refers to the inability of the entrepreneur to design and plan the key variables such as costs and production process, whereas ex post incompetence refers to the lack of experience, knowledge or capability of the entrepreneur in the implementation of the funded project (Schiavone, 2017). Specifically, ex ante creator incompetence can cause operations planning and supplychain planning delays, whereas ex post incompetence can result in project implementation and supply-chain management delays (Schiavone, 2017). Lastly, a study conducted by Hauge and Chimahusky (2016) included a sample of 288 Kickstarter projects across numerous product types funded from September 2011-March 2013. While $61 \%$ of these projects failed to deliver rewards on time, the authors found lateness in every category of product. In addition, they did not find significant relationships between variables such as the number of team members or prior exposure to Kickstarter, where the expectation was that those factors would have an impact. This may be accounted for by the way that they defined the variables. For example, team was defined by the number of team members, not on their individual relevant work experience or time working together as a team.

Findings of the prior studies highlight the importance of understanding the impact of entrepreneurs' individual-level factors such as lack of experience and capabilities of fulfilling the obligations of reward delivery in the RBC model. However, as we discussed earlier, RBC establishes a contractual relationship between entrepreneurs and investors, and hence, there is a lack of theoretical explanation of this common observation from the investors' perspective. To address this gap, we attempt to integrate individual-level factors of both entrepreneurs and investors in our theoretical framework. On the one hand, we speculate that entrepreneurial personality theory provides an important and relevant theoretical lens through which we can investigate whether some well-studied personality characteristics in entrepreneurship literature may explain the observed failures and delays in reward delivery. On the other hand, we argue that the lack of contractual details in the TOU of the RBC platforms and the lack of strict legal regulations in $\mathrm{RBC}$ will likely make the evaluations of obligation violations subject to individual perceptions by the investors. Since investors fund the project due to different motivators, we speculate that different types of motivators will likely influence the nature of exchange relationships between the investors and the entrepreneurs, which in turn, will affect investors' perceptions of violations of reward delivery obligations. We provide detailed discussion on our integrated theoretical framework in the section below.

\section{An integrated theoretical framework}

In this section, we apply entrepreneurial personality theory and psychological contract theory in building an integrated theoretical framework to develop propositions and identify
Perceptions in reward-based crowdfunding 
NEJE

24,1

48

factors that may explain variations in perceived violation of reward delivery obligations among investors. We summarize our propositions in Figure 1.

\section{Entrepreneurial personality theory; failures and delays in reward delivery}

Early entrepreneurship research in the 1960 and 70s adopted the classic trait approach and focused on identifying personality traits and characteristics that could differentiate entrepreneurs from nonentrepreneurs. For example, the most commonly studied entrepreneurial traits include the "Big Three" (Chell, 2008, p. 81) - need for achievement (e.g. McClelland, 1961; McClelland and Winter, 1969), locus of control (e.g. Liles, 1974) and risk-taking propensity (e.g. Liles, 1974). Later studies examined the relationships between broad personality traits, namely the Big Five or the five-factor model (openness, extroversion, agreeableness, neuroticism and conscientiousness) and entrepreneurial behaviors and outcomes, such as venture survival (Ciavarella et al., 2004) as well as risk propensity and entrepreneurial performance (Zhao et al., 2010). Brandstätter (2011) provided clear empirical evidence of the relevance of personality traits (e.g. risk propensity, achievement motivation and Big Five personality) in entrepreneurship research. These findings provide support to the entrepreneurial personality research and suggest that personality does play a role in explaining entrepreneurial behaviors and outcomes.

In addition to these personality traits, researchers have called for more attention to the fact that personality traits can be multifaceted, with positive traits potentially having a dark side (Hmieleski and Baron, 2008; Kets de Vries, 1977, 1985; Kets de Vries and Miller, 1985; Klotz and Neubaum, 2016; Miller 2015, 2016). Indeed, the Big-Five personality model was criticized for not being inclusive (O'Boyle et al., 2014) and does not include potential negative traits that could be relevant to entrepreneurial behavior, including Machiavellianism, egotism, risktaking, overconfidence, narcissism and others (Miller, 2016). Hmieleski and Baron (2008) argue that, in certain circumstances, high levels of self-efficacy can encourage complacency and overconfidence and result in negative effects on entrepreneurial firm performance. Similarly, Miller (2015) argues that self-efficacy and self-assurance may turn into hubris and narcissism; one's desire for achievement and influence can lead to behaviors that cut corners and disregard stakeholders.

To better understand the impact the negative personality traits and new venture performance, Klotz and Neubaum (2016) suggest that future research examines the dark triad (DT), which includes Machiavellianism, narcissism, and psychopathy (O'Boyle et al., 2014). Specifically, individuals who have a high level of Machiavellianism usually advocate the use of manipulative tactics in dealing with others; people with narcissistic traits often hold exceedingly high and unrealistic views of themselves, which they express through claims of entitlement, grandiosity and a rejection of negative feedback; individuals with psychopathic traits are emotionally callous, impulsive and lack empathy (O'Boyle et al., 2014). According to O'Boyle et al. (2014), DT traits may supplement the Big Five Factor model by focusing on less desirable personality traits.

Figure 1.

A conceptual framework of factors related to perceived violations of reward obligations in the RBC Model

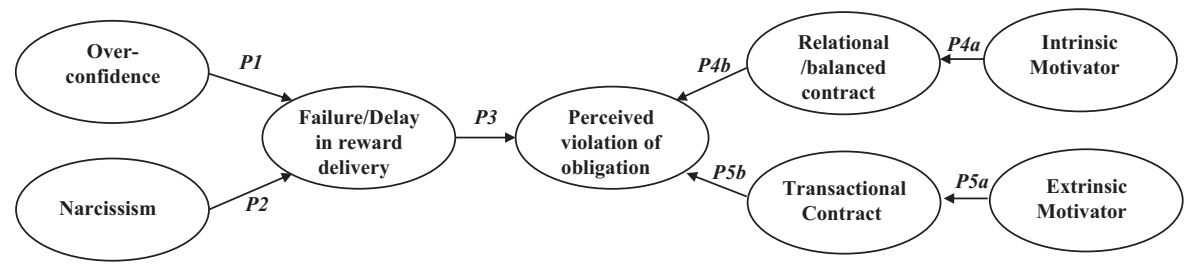


Researchers in the field of entrepreneurship have recently examined psychological factors in the context of entrepreneurial mistakes and failures with a specific focus on overconfidence and narcissism (e.g. Artinger and Powell, 2016; Chen et al., 2018; Hogarth and Karelaia, 2012; Invernizzi et al., 2017; Liu et al., 2019; Navis and Ozbek, 2017). In the context of RBC, we believe that entrepreneurial personality theory provides a relevant theoretical lens through which we can identify specific entrepreneurial personality traits that may partially explain the observed common failures and delays in reward delivery. As we discussed earlier, previous studies (e.g. Mollick, 2014) found that fraud accounts for a relatively small portion of delays which would potentially be explained by Machiavellianism. Therefore, in the context of RBC, we consider Machiavellianism irrelevant and focus on two entrepreneurial dark traits - overconfidence and narcissism.

Indeed, overconfidence and narcissism are considered to be relevant but distinct constructs because one can be overconfident without being a narcissist and one can be a narcissist without being overconfident (Navis and Ozbek, 2017). These two constructs tend to be related because narcissists tend to have inflated self-assessment of their skills and abilities (Campbell et al., 2004a, b). Individuals with a high level of narcissism tend to reject negative feedback from others which can lead to incorrect decisions and poor task performance (Campbell et al., 2004a, b). Campbell et al. (2004a, b) attributed the underperformance of narcissists to their inflated performance estimates made prior to engaging in the task. In the context of $\mathrm{RBC}$, in our review of reasons for the failure to meet reward delivery obligations in reward-based crowdfunding, a significant number of the reasons identified in the literature fall into the category of project management, inexperience in operations and poor planning and budgeting, which, in our view, can be negatively impacted by entrepreneurs' overconfidence and narcissism, or an inflated assessment of capabilities.

Previous research has shown that self-efficacy, or the degree to which people perceive themselves as having the ability to successfully perform the various roles and tasks of entrepreneurship (Chen et al., 1998), may not always generate improved levels of performance; and on the contrary, may encourage overconfidence (i.e. an overestimation of one's own ability to make accurate forecasts) (Koellinger et al., 2005) and complacency, which, in turn, lead to negative organizational outcomes (e.g. Vancouver and Kendall, 2006; Vancouver et al., 2002). In an empirical study, Hmieleski and Baron (2008) found that the combination of high self-efficacy and high dispositional optimism, defined as general positive outcome expectancy, can have negative effects on firm performance especially in a dynamic environment. Hmieleski and Baron (2008) further argue that this combination could lead entrepreneurs to be overconfident and to conclude, perhaps erroneously, that they can perform all essential tasks very well and that doing so is very likely to result in positive outcomes. Such overconfidence can be especially damaging in the dynamic environment in which the rate of unpredicted change occurring within a given industry continues to increase (Hmieleski and Baron, 2008).

Busenitz and Barney (1994) examined entrepreneurial overconfidence and the representativeness heuristic. While a high level of confidence in their decision-making ability is important to keep them from being overwhelmed with the multiple hurdles they face, it can often lead the entrepreneur to rely on a representativeness heuristic. It is important to note that this research focused on the difference between large company managers and entrepreneurs. In a structured corporate environment, there are normally multiple levels of management and multiple internal reviews that any new product must undergo. Each step of the way there are normally procedures and processes to follow. As the paper points out, entrepreneurs perceive less risk than managers, but this may be due in part to the fact that managers in a corporate environment are "forced" by their process to address risks in each step while entrepreneurs in an RBC situation are not. Tversky and Kahneman (1974) defined a relation between a hypothetical process and some event associated with the process. This
Perceptions in reward-based crowdfunding 
NEJE

24,1

heuristic suggests that entrepreneurial decision makers tend to oversimplify alternative outcomes based on current knowledge and apply it to personal rules that have emerged from prior experiences. An entrepreneur is likely to base a decision on a small sample or past experience in order to move ahead with an untested product in a relatively new market because that may be all that exists. The more extensive use of overconfidence and representativeness bias by an entrepreneur is likely to lead them to the perception of a lower level of risk (Busenitz and Barney, 1994). Artinger and Powell (2016) also examined how overconfidence can distort entrepreneurial decisions and lead to entrepreneurs' mistakes in excess entry. Similarly, Chen et al. (2018) examined the impact of overconfidence in modifying the entrepreneurs' learning process, altering the pattern of entry and exit decisions. Invernizzi et al. (2017) found that the majority of entrepreneurs were prone to overconfident budgetary forecasts which were directly associated with firm failure.

Narcissism is described as a socially defined construct with the two key elements being a positive, inflated view of the self and a self-regulatory strategy to maintain and enhance this positive self-view (Morf and Rhodewalt, 2001). Narcissists usually are concerned with actions that reflect favorably upon themselves (Wales et al., 2013) and think that they are special and unique (Emmons, 1984), which can lead to a sense of entitlement to more positive outcomes in life than others (Campbell et al., 2004a, b), self-admiration and hostility towards external criticism (Judge et al., 2006). According to Kets de Vries and Miller (1985), a narcissistic individual is "... independent and impossible to intimidate. Significant aggressiveness is possible, which sometimes manifests itself in a constant readiness for activity" (p. 6).

In terms of self-regulatory strategies to reinforce their inflated view, narcissists strategically attribute responsibility for their own success to ability (e.g. Campbell et al., 2000). They focus on success and achievement with little fear of failure or poor performance (Elliot and Thrash 2001). Narcissistic entrepreneurs usually do not attend to objective cues but are motivated to employ ego-defensive strategies to maintain self-esteem and superiority (Brown, 1997). Campbell et al. (2004a, b) study looked at decision-making as an area where narcissism distorted decision-making due to overconfidence. They examined the links between narcissism, overconfidence, risk-taking and performance and found that narcissism was positively linked to overconfidence, that narcissists took greater risks in tasks based on their own knowledge and performed more poorly in those tasks. In addition, they found that narcissists were overconfident due to inflated ability estimates and that they remain positive about their abilities and performance even when faced with poor performance. Underperforming narcissists reported that they overperformed (Campbell et al., 2004a, b), rather than admit failure.

In the context of $\mathrm{RBC}$, we believe that online crowdfunding presents a dynamic environment where the demands and expectations of the investors are constantly changing and the availability and quality of information essential for strategic decision-making is not always available due to information asymmetry between the entrepreneur and the investor. In addition, the analysis by Schiavone (2017) indicates that the majority of product delays are due to logistical and management mistakes encountered in the launch of a new product, which can be difficult to manage even for an experienced entrepreneur. These delays can be exacerbated by a lack of operating experience, incompetence and the "can do" confidence of most entrepreneurs who may view operational issues as being of secondary importance rather than their vision for the product. In other words, entrepreneurs may not view the actual creation and delivery of the rewards as risky, despite the fact that they have never created this specific product or delivered it in any significant volume in the past.

From this perspective, entrepreneurs who score high on overconfidence are likely to overestimate their ability to make accurate forecasts of whether they can fulfill the reward delivery obligations and are likely to underestimate the practical constraints and costs associated with management, operational and logistical issues, resulting in failures and 
delays in delivering rewards to investors. Similarly, we speculate that entrepreneurs with narcissistic traits are also likely to unrealistically assess their ability and may reject negative but constructive feedback in the implementation process, hence leading to reward delivery failures and delays. Therefore, we expect that,

Proposition 1. In RBC, the level of the entrepreneur's overconfidence is positively associated with the likelihood that the entrepreneur will encounter failures and delays in delivering rewards to investors.

Proposition 2. In RBC, the level of the entrepreneur's narcissism is positively associated with the likelihood that the entrepreneur will encounter failures and delays in delivering rewards to investors.

\section{Psychological contract and perceived violations of reward delivery obligations}

Prior research has examined motivations of investors and entrepreneurs. Van Wingerden and Ryan's (2011) study showed that there are two major groups of crowdfunders: those who participated for extrinsic reasons and monetary rewards and those who engage for intrinsic reasons and nonmonetary rewards. In extrinsic motivation, the main reason lies in the reward itself. In other words, through $\mathrm{RBC}$, investors can have access to a product or a solution at a reasonable price that is otherwise unavailable elsewhere. Investors may also value the symbolic value or formal recognition of receiving a product, hence another extrinsic motivation. In intrinsic motivation, investors participated for intrinsic reasons, such as having creative input into the product and for the simple fun of it. It is important to note that, according to Van Wingerden and Ryan (2011), extrinsic and intrinsic motivations do not seem to influence the funding decision at the same time. Van Wingerden and Ryan (2011) state that "the crowdfunders who do have the possibility to earn a monetary reward based on platform choice generally do not fund a project for the fun of it, do not feel that helping someone reach their goal is more important than getting a reward, nor do they feel that being involved in the process is a reward in itself" (p. 51).

Consistent with findings of Van Wingerden and Ryan's (2011) study, recent studies also revealed and discussed the heterogeneity in motivators of both entrepreneurs and investors (e.g. Colombo et al., 2015; Gerber et al., 2016). For example, Colombo et al. (2015) maintain that entrepreneurs are motivated to use the online crowdfunding platforms not only to raise money for product development, but also to validate their business ideas, connect with others in the community or increase awareness of their work through social media. Gerber et al. (2016) conducted a qualitative exploratory study of entrepreneurs and investors and found that in addition to an anticipated extrinsic motivator such as securing funding (extrinsic), people were also motivated to participate to strengthen social interactions and commitment to an idea through feedback and to develop feelings of connectedness to a community with similar interests and ideals. Similarly, Moss et al. (2015) examined the impact of intrinsic (i.e. framing a venture as an opportunity to help others) versus extrinsic cues (i.e. framing a venture as a business opportunity) on crowdfunding performance.

Collectively, these studies highlight the importance of types of motivators (intrinsic versus extrinsic) in understanding the investors' funding decisions and the success of the crowdfunding campaigns. In the context of RBC, it is likely that entrepreneurs' failures and delays in reward delivery may be perceived by investors as violations of reward obligation. However, we speculate that due to different types of investor motivators, variations may exist in perceived violations. We believe that investors' motivators are of particular importance in understanding the nature of the relations formed with a particular entrepreneur or creator, which, in turn, will influence the perceived violations of obligations (i.e. failures or delay in reward delivery). Indeed, the nature of the exchange relationship and perceptions of

Perceptions in reward-based crowdfunding

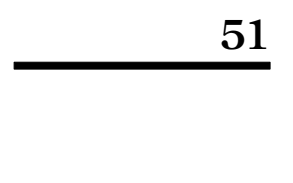


NEJE

24,1

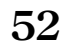

obligation violations have been examined in the psychological contract literature. The psychological contract is broadly defined as an individual's beliefs about the terms of an exchange agreement between the individual and the organization (Rousseau, 1995, 2004). Psychological contracts have also been shown to influence key organizational outcomes, such as job satisfaction, intent to stay with the organization and trust in the organization (Rousseau, 1995; Turnley and Feldman, 2000). In addition, when a breach occurs, employees tend to perform more poorly, engage in greater job search activities and move backward on job performance or organizational citizenship behavior (Robinson and Rousseau, 1994). From this perspective, psychological contracts are considered an important indicator of the nature of employment relationships.

According to Rousseau (1995), there are four types of psychological contracts: transactional, relational, balanced and transitional. Transactional contracts are short-term exchanges of specific benefits and contributions that are monetary or economic in focus. A relational contract refers to a long-term arrangement without specific performance-reward contingencies. Balanced contracts combine an open-ended relational emphasis with the transactional feature of well-specified performance-reward contingencies. Lastly, transitional agreements, however, reflect a breakdown or absence of an agreement between the parties as in unstable circumstances (e.g. layoffs or radical change) in which commitments between the parties are eroded or do not exist.

In the context of $\mathrm{RBC}$, we speculate that transactional, relational and balanced contracts are of particular relevance and can explain the nature of the exchange relationships formed between the entrepreneur and the investors. Specifically, we speculate that investors who engage in an $\mathrm{RBC}$ project due to intrinsic motivators, such as supporting a cause or a family member/friend, having fun and being part of the creative process or the community, are more likely to view their relationships with the entrepreneurs as relational or balanced contracts. In this case, investors derive satisfaction from, being part of something new or developing a sense of connectedness to a community, and hence are less likely to be highly calculative and short-term oriented when evaluating entrepreneurs' fulfillment of reward delivery obligations. Therefore, in cases in which rewards are delayed or failed to be delivered, we expect that these investors are less likely to perceive violations of reward obligations. In contrast, when investors participate due to extrinsic motivators, they are more likely to form a transactional psychological contract with the entrepreneurs. In the latter case, the investors derive satisfaction from the receipt of the rewards, and hence are more likely to pay close attention to the short-term fulfillment of specific rewards, leading to a higher likelihood of perceived obligation violations. Hence, we propose that.

Proposition 3. In RBC, entrepreneurs' failures and delays in reward delivery will be perceived by investors as violations of reward obligations.

Proposition $4 a$. In RBC, investors with intrinsic motivators are likely to form relational or balanced psychological contracts with entrepreneurs.

Propositions 4b. In RBC, investors with relational or balanced psychological contracts are less likely to perceive the failures or delays in reward delivery as obligation violations.

Proposition 5a. In $\mathrm{RBC}$, investors with extrinsic motivators are likely to form transactional psychological contracts with entrepreneurs.

Propositions 5b. In RBC, investors with transactional psychological contracts are more likely to perceive the failures or delays in reward delivery as obligation violations. 


\section{Discussions}

In this paper, we studied a common observation in the implementation stage of the RBC model - entrepreneurs' failures and delays in delivering rewards to investors. Our paper presents an integrated theoretical model which may explain the perceived violation of reward delivery obligations. As the $\mathrm{RBC}$ model is based on the contractual relationship between entrepreneurs and the investors, our theoretical analysis contributes to the crowdfunding literature by being the first to explore individual-level factors related to both entrepreneurs and investors in explaining variations in perceived violation of reward delivery obligations. We examined two previously understudied psychological factors in the context of RBC entrepreneurial traits, mainly overconfidence and narcissism and the type of psychological contracts formed between investors and entrepreneurs, both of which, according to McKenny et al. (2017), need greater attention from researchers studying crowdfunding.

First, our analysis extends these prior studies by examining failures and challenges in the implementation stage after the entrepreneurs have successfully raised funds and met their funding goals. Although recent research has identified reasons behind the observed high percentage of delays in delivering rewards to investors, there is a lack of theoretical explanation of why such failures and delays commonly occur. To bridge this gap, we applied entrepreneurship personality theory, in particular the literature on overconfidence and narcissism, in explaining the role of the entrepreneur's personality in causing the unintentional failures and delays in reward delivery. In addition, we argue that due to the lack of contractual details in the TOU used by most online crowdfunding platforms and limited legal regulation of the $\mathrm{RBC}$ model, the evaluation of reward obligation violation may be subject to investors' personal assessment and individual perceptions. To address this issue, we apply psychological contract theory and explicate the relationships between investors' motivators and the nature of psychological contracts they may form with entrepreneurs, which in turn, will likely have an impact on the perceived violation of reward obligation. Although recent studies (e.g. André et al., 2017) have started paying attention to the exchange relationship between the investors and the entrepreneurs in the context of crowdfunding, to our knowledge, we are the first to apply psychological contract theory in explaining the formation of different types of psychological contracts between investors and entrepreneurs, hence providing a more refined understanding and explanation of variations in investors' expectations and their evaluations of entrepreneurs' fulfillment of these expectations.

In short, our theoretical analysis, by wielding two independently developed literatures, has demonstrated that it is important to investigate factors that are related to both investors and entrepreneurs in understanding issues and challenges at different stages of the RBC model. We believe that the current analysis provides an integrated understanding and a solid foundation for researchers to further examine these issues by empirically testing these propositions. Due to the scope of the paper, our analysis was limited to the individual-level factors. We encourage future research to examine other related factors which may interact with the individual-level factors in explaining the observed issues and challenges associated with RBC. For example, future research may further explicate the role of the online crowdfunding platforms and regulatory agencies in strengthening legal regulation of RBC.

Informed by the prior research related to pre-entry learning for entrepreneurs, we believe that unintentional violations can be reduced with entrepreneurial education and learning. For example, as Fong and Nisbett (1991) noted, decision biases can be corrected through training. Chen et al. (2018) characterized entrepreneurship as the unfolding feedback-learning process and their model indicated that pre-entry learning activities have substantial positive implications for the entry decision and varying the length and quality of pre-entry learning shows how experience remedies certain biases, though not all bias. Similarly, Ivernizzi et al. (2017) suggest that entrepreneurs' overconfidence can be mitigated by their level of
Perceptions in reward-based crowdfunding 
NEJE

24,1

\section{4}

educational attainment and the use of budgetary controls. Moreover, Liu et al. (2019) suggest that highly narcissistic entrepreneurs need to be aware of their tendency to deny or justify failure to maintain their sense of superiority so that they can learn from their failures. Future research may further explore the interaction effects of entrepreneurial personality traits and pre-entry learning on fulfilling reward delivery obligations.

Lastly, researchers may also conduct an ethical analysis of RBC by focusing on concepts such as moral hazard in RBC. Moral hazard focuses on how behavior changes when individuals know that they will not be required to bear the burden of the risks that they take or are insulated from harm (often through insurance) (Finkelstein et al., 2015). It occurs in situations where there is information asymmetry between the parties, where the behavior of one party cannot be consistently monitored by the other party, and potentially, where there is a lack of good faith by the party who is insulated from the risk (Finkelstein et al., 2015). In $\mathrm{RBC}$, because the products are new and the behavior of the entrepreneur cannot be consistently monitored by the investor, there is clearly information asymmetry between the entrepreneur and the investor. In this case, future research may conduct study and examine how such moral hazard can be questioned and tackled.

Indeed, scholars (e.g. Gutierrez and Saez, 2018) have called for additional legal restrictions and more formal contract requirements for RBC. Gutierrez and Saez (2018) used the term "no-penalty contract" to describe the existing contract terms in RBC and developed a model to compare the standard presell contract penalties against the no-penalty contract. Their study indicates that the current no penalty contract is the best model in order to encourage the risktaking that is a part of new product development and entrepreneurship. However, their work focused more on the goodwill created between entrepreneurs and investors and the need for the entrepreneur to prove his or her talent in order to raise funds. It did not focus on the other aspects of legal mechanisms to improve investor protection and also did not explore ethical issues in RBC, especially when dealing with small, start-up businesses with relatively low dollar values for each individual involved. Given the relatively low cost of an average reward (\$76), the time and money involved to pursue a private lawsuit is not economically justified and the average filing fee in small claims court (\$95) is actually larger than the typical amount of the cost of the product reward in the $\mathrm{RBC}$ model. Also, most entrepreneurial ventures, even if they have incorporated, are start-ups, and hence financial resources available to pay a settlement are often limited or nonexistent. This means that winning a court verdict is of limited value financially. Those individuals who choose to go to court "because of the principle involved" would find this a costly process. From this perspective, we believe that how to address these legal issues is of both practical and theoretical importance. While this may add to the cost and complexity of $\mathrm{RBC}$, it would also require entrepreneurs to overcome their personality traits by conducting more in-depth budgeting, planning and due diligence, which may satisfy the investors "as to the principle involved". This will also require entrepreneurs to have a better handle on their production costs and to prioritize expenditures. In addition, we believe that a more formal and detailed ethical code of conduct focused on the preparation needed to fulfill reward obligations can be effective in reducing failures and delays in reward delivery later.

Our analysis and discussion have implications for practice. Our analysis highlights the importance of the pre-entry due diligence and learning of the entrepreneur. We believe that improved preparation will likely reduce the number of delays in reward delivery and influence the perception of whether a delay, under certain circumstances, is a violation of the delivery obligation. As stated previously in the paper, investors who view the contractual relationship as balanced or relational, may be less likely to view a delay of rewards delivery as a violation of the delivery obligation. We speculate that those same investors would be even less likely to view a delay as a violation if they believed that the entrepreneur had done an appropriate level of due diligence and "made best efforts" in preparation of rewards delivery. 
For example, did the entrepreneur take the time to lay out an effective supply chain, fulfillment and shipping plan? Did he or she take the time to lay out a formal budget for the production and delivery of the product? Did the entrepreneur have a contingency plan if the supplier failed? We speculate that investors who are intrinsically motivated will view the "best efforts" of the entrepreneur as sufficient to consider them not in violation of the delivery obligation.

Also, as stated earlier in the paper, prior research related to pre-entry learning (Chen et al., 2018; Fong and Nisbett, 1991; Ivernizzi et al., 2017) indicates that certain decision biases of entrepreneurs as well as the effect of their overconfidence can be mitigated through pre-entry learning and budgeting. While it may not be desirable to overburden an entrepreneur with exhaustive due diligence, it may be possible to provide a reasonable project management checklist or sample legal questions that must be answered, with the answers available on the fundraising page for the project. Since prior research (Mollick, 2014) indicated that many of the delivery problems are related to shipping, manufacturing and similar operating issues, this added requirement may also improve both perception and on-time delivery.

\section{Conclusion}

Crowdfunding has proven to be a major force in funding new products and creative endeavors, especially for smaller funding efforts which may not be attractive to traditional providers of capital. Among four types of crowdfunding, we believe that the RBC model presents unique challenges and issues due to the lack of contractual details in the TOU and limited legal regulation. Nonetheless, in order to keep this channel of funding flowing, it is important that investors are being dealt with fairly by entrepreneurs and that entrepreneurs have done the necessary preparation to deliver rewards in a timely manner. Much of the academic research done on $\mathrm{RBC}$ involved determining the level of fraud, variables that can increase the likelihood of funding, practical reasons behind project delays, and legal issues in crowdfunding from a contractual viewpoint. We suggest that additional research into the personality traits of entrepreneurs and the nature of exchange relationships between entrepreneurs and investors can help further explicate the root causes of the observed issues and challenges in RBC. We suggest that researchers pay more attention to the moral and ethical issues of $\mathrm{RBC}$ so that an appropriate balance between enhanced ethical and legal protections can be determined, leading to positive outcomes for both entrepreneurs and investors.

\section{References}

Adams, K. (2004), "Understanding best efforts and its variants", Practical Lawyer, available at: https:// adamsdrafting.com/downloads/Best-Efforts-Practical-Lawyer.pdf (accessed 10 August 2019).

Agrawal, A., Catalini, C. and Goldfarb, A. (2014), "Some simple economics of crowdfunding", Innovation Policy and the Economy, Vol. 14, pp. 63-97.

Ahlers, G.K., Cumming, D., Günther, C. and Schweizer, D. (2015), "Signaling in equity crowdfunding", Entrepreneurship: Theory and Practice, Vol. 39 No. 4, pp. 955-980.

Allison, T.H., Davis, B.C., Short, J.C. and Webb, J.W. (2015), "Crowdfunding in a prosocial microlending environment: examining the role of intrinsic versus extrinsic cues", Entrepreneurship: Theory and Practice, Vol. 39 No. 1, pp. 53-73.

André, K., Bureau, S., Gautier, A. and Rubel, O. (2017), "Beyond the opposition between altruism and self-interest: reciprocal giving in reward-based crowdfunding", Journal of Business Ethics, Vol. 146 No. 2, pp. 313-332.
Perceptions in reward-based crowdfunding 
NEJE

24,1
Artinger, S. and Powell, T.C. (2016), "Entrepreneurial failure: statistical and psychological explanations", Strategic Management Journal, Vol. 37 No. 6, pp. 1047-1064, doi: 10.1002/ smj.2378.

Belleflamme, P., Lambert, T. and Schwienbacher, A. (2014), "Crowdfunding: tapping the right crowd", Journal of Business Venturing, Vol. 29 No. 5, pp. 585-609.

Black's Law Dictionary (1990), Black's Law Dictionary, 6th ed.

Brandstätter, H. (2011), "Personality aspects of entrepreneurship: a look at five meta-analyses", Personality and Individual Differences, Vol. 51 No. 3, pp. 222-230.

Brown, A.D. (1997), "Narcissism, identify, and legitimacy", Academy of Management Review, Vol. 22 No. 3, pp. 643-686.

Buff, L.A. and Alhadeff, P. (2013), "Budgeting for crowdfunding rewards", Journal of the Music and Entertainment Industry Educators Association, Vol. 13 No. 1, pp. 27-44.

Busenitz, L. and Barney, J. (1994), "Biases and heuristics in strategic decision making: differences between entrepreneurs and managers in large organizations", Academy of Management Best Papers Proceedings, Vol. 54, pp. 85-89.

Campbell, W.K., Reeder, G.D., Sedikides, C. and Elliot, A.J. (2000), "Narcissism and comparative selfenhancement strategies", Journal of Research in Personality, Vol. 34 No. 3, pp. 329-347.

Campbell, W.K., Goodie, A.S. and Foster, J.D. (2004a), "Narcissism, confidence, and risk attitude", Journal of Behavioral Decision Making, Vol. 17 No. 4, pp. 297-311.

Campbell, W.K., Bonacci, A.M., Shelton, J., Exline, J.J. and Bushman, B.J. (2004b), "Psychological entitlement: interpersonal consequences and validation of a self-report measure", Journal of Personality Assessment, Vol. 83 No. 1, pp. 29-45.

Chell, E. (2008), The Entrepreneurial Personality: A Social Construction, Routledge, New York, NY.

Chen, C.C., Greene, P.G. and Crick, A. (1998), "Does entrepreneurial self-efficacy distinguish entrepreneurs from managers?", Journal of Business Venturing, Vol. 13, pp. 295-316.

Chen, J.S., Croson, D.C., Elfenbein, D.W. and Posen, H.E. (2018), "The impact of learning and overconfidence on entrepreneurial entry and exit", Organization Science, Vol. 29 No. 6, pp. 989-1009.

Ciavarellala, M.A., Buchholtz, A.K., Riordan, C.M., Gatewood, R.D. and Stokes, G.S. (2004), "The big five and venture survival: is there a linkage", Journal of Business Venturing, Vol. 19 No. 4, pp. $465-483$.

Ciuchta, M.P., Letwin, C., Stevenson, R., McMahon, S. and Huvaj, M.N. (2018), "Betting on the coachable entrepreneur: signaling and social exchange in entrepreneurial pitches", Entrepreneurship: Theory and Practice, Vol. 42 No. 6, pp. 860-885.

Colombo, M.G., Franzoni, C. and Rossi-Lamastra, C. (2015), "Internal social capital and the attraction of early contributions in crowdfunding", Entrepreneurship: Theory and Practice, Vol. 39 No. 1, pp. $75-100$.

Cumming, D.J., Hornuf, L., Karami, M. and Schweizer, D. (2016), "Disentangling crowdfunding from fraudfunding”, SSRN Electronic Journal. doi: 10.2139/ssrn.2828919 (accessed 9 August 2019).

Davis, B.C., Hmieleski, K.M., Webb, J.W. and Coombs, J.E. (2017), "Funders' positive affective reactions to entrepreneurs' crowdfunding pitches: the influence of perceived product creativity and entrepreneurial passion", Journal of Business Venturing, Vol. 32, pp. 90-106.

Elliot, A.J. and Thrash, T.M. (2001), "Narcissism and motivation", Psychological Inquiry, Vol. 12, pp. 216-219.

Emmons, R.A. (1984), "Factor analysis and construct validity of the narcissistic personality inventory", Journal of Personality Assessment, Vol. 48, pp. 291-300.

Finkelstein, A., Newhouse, J.P., Stiglitz, J.E., Arrow, K.J. and Gruber, J. (2015), Moral Hazard in Health Insurance, Columbia University Press, New York, NY. 
Fong, G.T. and Nisbett, R.E. (1991), "Immediate and delayed transfer of training effects in statistical reasoning”, Journal of Experimental Psychology: General, Vol. 120 No. 1, pp. 34-45.

Ganatra, J.H. (2016), "When Kickstarter stops: exploring failures and regulatory frameworks for the rewards-based crowdfunding industry", Rutgers University Law Review, Vol. 68 No. 3, pp. 1425-1472.

Gerber, E.M., Hui, J.S. and Kuo, P.-Y. (2016), "Crowdfunding: why people are motivated to post and fund projects on crowdfunding platforms", Proceedings of the International Workshop on Design, Influence, and Social Technologies: Techniques, Impacts and Ethics.

Gutiérrez, U.M. and Sáez, L.M. (2018), "The promise of reward crowdfunding”, Corporate Governance: An International Review, Vol. 26 No. 5, pp. 355-373.

Hauge, J.A. and Chimahusky, S. (2016), "Are promises meaningless in an uncertain crowdfunding environment? Lateness in crowdfunding”, Economic Inquiry, Vol. 54 No. 3, pp. 1621-1630.

Hmieleski, K.M. and Baron, R.A. (2008), "When does entrepreneurial self-efficacy enhance versus reduce firm performance", Strategic Entrepreneurship Journal, Vol. 2 No. 1, pp. 57-72.

Hogarth, R.M. and Karelaia, N. (2012), "Entrepreneurial success and failure: confidence and fallible judgement”, Organization Science, Vol. 23, pp. 1733-1747.

Invernizzi, A.C., Menozzi, A., Passarani, D.A., Patton, D. and Viglia, G. (2017), "Entrepreneurial overconfidence and its impact upon performance", International Small Business Journal, Vol. 35 No. 6, pp. 709-728.

Judge, T.A., LePine, J.A. and Rich, B.L. (2006), "Loving yourself abundantly: relationship of the narcissistic personality to self- and other perceptions of workplace deviance, leadership, and task and contextual performance", Journal of Applied Psychology, Vol. 91 No. 4, pp. 762-776.

Kappel, T. (2009), "Ex ante crowdfunding and the recording industry: a model for the U.S., Loyola of Los Angeles Entertainment Law Review, Vol. 29, pp. 375-385.

Kets de Vries, M. (1977), "The entrepreneurial personality: a person at the crossroads", Journal of Management Studies, Vol. 14 No. 1, pp. 34-57.

Kets de Vries, M. (1985), “The dark side of entrepreneurship”, Harvard Business Review, Vol. 63 No. 3, pp. 160-167.

Kets de Vries, M. and Miller, D. (1985), "Narcissism and leadership: an object relations perspective", Human Relations, Vol. 38 No. 6, pp. 583-601.

Klotz, A.C. and Newbaum, D.O. (2016), "Research on the dark side of personality traits in entrepreneurship: observations from an organizational behavior perspective", Entrepreneurship: Theory and Practice, Vol. 40 No. 1, pp. 7-17.

Koellinger, P., Minniti, M. and Schade, C. (2005), “I think I can, I think I can': overconfidence and entrepreneurial behavior", DIW Discussion Papers, No. 501, Deutsches Institut für Wirtschaftsforschung (DIW), Berlin.

Li, J., Chen, X., Kotha, S. and Fisher, G. (2017), "Catching fire and spreading it: a glimpse into displayed entrepreneurial passion on crowdfunding campaigns", Journal of Applied Psychology, Vol. 102 No. 7, pp. 1075-1090.

Liles, P. (1974), “Who are the entrepreneurs?”, MSU Business Topics, Vol. 22, pp. 5-14.

Liu, Y., Li, Y., Hao, X. and Zhang, Y. (2019), "Narcissism and learning from entrepreneurial failure", Journal of Business Venturing, Vol. 34 No. 3, pp. 496-512.

McClelland, D.C. (1961), The Achieving Society, Van Nostrand, Princeton, NJ.

McClelland, D.C. and Winter, D.G. (1969), Motivating Economic Achievement, Free Press, New York, NY.

McKenny, A.F., Allison, T.H., Ketchen, D.J., Short, J.C. and Ireland, R.D. (2017), "How should crowdfunding research evolve?: a survey of the entrepreneurship theory and practice editorial board", Entrepreneurship: Theory and Practice, Vol. 41 No. 2, pp. 291-304.

Perceptions in reward-based crowdfunding 
NEJE

24,1

Miller, D. (2015), “A downside to the entrepreneurial personality", Entrepreneurship: Theory and Practice, Vol. 39 No. 1, pp. 1-8.

Miller, D. (2016), "Response to research on the dark side of personality traits in entrepreneurship: observations from an organizational behavior perspective", Entrepreneurship: Theory and Practice, Vol. 40 No. 1, pp. 19-24.

Mollick, E. (2014), "The dynamics of crowdfunding: an exploratory study", Journal of Business Venturing, Vol. 29 No. 1, pp. 1-16.

Mollick, E.R. (2015), "Delivery rates on Kickstarter”, SSRN Electronic Journal. doi: 10.2139/ssrn. 2699251 (accessed 9 August 2019).

Moores, C. (2015), "Kickstart my lawsuit: fraud and justice in rewards-based crowdfunding”, UC Davis Law Review, Vol. 49 No. 1, pp. 383-424.

Morf, C.C. and Rhodewalt, F. (2001), "Unraveling the paradoxes of narcissism: a dynamic selfregulatory processing model”, Psychological Inquiry, Vol. 12, pp. 177-196.

Moss, T.W., Newbaum, D.O. and Meyskens, M. (2015), "The effect of virtuous and entrepreneurial orientations on microfinance lending and repayment: a signaling theory perspective", Entrepreneurship: Theory and Practice, Vol. 39, pp. 27-52.

Navis, C. and Ozbek, O.V. (2017), "Why context matters: overconfidence, narcissism, the role of objective uncertainty in entrepreneurship", Academy of Management Review, Vol. 42 No. 1, pp. 148-153.

O’Boyle, E.H., Forsyth, D.R., Banks, G., Story, P.A. and White, C.D. (2014), "A meta-analytic test of redundancy and relative importance of the dark triad and five-factor model of personality", Journal of Personality, Vol. 83 No. 6, pp. 644-664.

Robinson, S.L. (1996), "Trust and breach of the psychological contract", Administrative Science Quarterly, Vol. 41 No. 4, pp. 574-599.

Robinson, S.L. and Rousseau, D.M. (1994), "Changing obligations and the psychological contract: a longitudinal study", Academy of Management Journal, Vol. 37 No. 1, pp. 137-152.

Rousseau, D.M. (1995), Psychological Contracts in Organizations: Understanding Written and Unwritten Agreements, Sage, Thousand Oaks, CA.

Rousseau, D.M. (2004), "Psychological Contracts in the workplace: understanding the ties that motivate", Academy of Management Perspectives, Vol. 18 No. 1, pp. 120-127.

Schiavone, F. (2017), "Incompetence and managerial problems delaying reward delivery in crowdfunding", Journal of Innovation Economics, Vol. 23 No. 2, pp. 185-207.

Scott, R.E. and Triantis, G.G. (2006), "Anticipating litigation in contract design”, Yale Law Journal, Vol. 115 No. 4, pp. 814-879.

Short, J.C., Ketchen, D.J., McKenny, A.F., Allison, T.H. and Ireland, R.D. (2017), "Research on crowdfunding: reviewing the (very recent) past and celebrating the present", Entrepreneurship: Theory and Practice, Vol. 41 No. 2, pp. 149-160.

Turan, S.S. (2015), "Stakeholders in equity-based crowdfunding: respective risks over the equity crowdfunding lifecycle", Journal of Financial Innovation, Vol. 1 No. 2, pp. 141-151.

Turnely, W.H. and Feldman, D.C. (2000), "Re-examining the effects of psychological contract violations: unmet expectations and job dissatisfaction as mediators", Journal of Organizational Behavior, Vol. 21, pp. 25-42.

Tversky, A. and Kahneman, D. (1974), "Judgment under uncertainty: heuristics and biases”, Science, Vol. 185 No. 4157, pp. 1124-1131.

Van Wingerden, R. and Ryan, J. (2011), Fighting for Funds: An Exploratory Study into the Field of Crowdfunding, Lund University, School of Economics and Management, Lund.

Vancouver, J.B. and Kendall, L.N. (2006), "When self-efficacy negatively relates to motivation and performance in a learning context", Journal of Applied Psychology, Vol. 91 No. 5, pp. 1146-1153. 
Vancouver, J.B., Thompson, C.M., Tishchner, E.C. and Putka, D.J. (2002), "Two studies examining the negative effect of self-efficacy on performance", Journal of Applied Psychology, Vol. 87 No. 3, pp. 506-516.

Wales, W.J., Patel, P.C. and Lumpkin, G.T. (2013), "In pursuit of greatness: CEO narcissism, entrepreneurial orientation, and firm performance variance", Journal of Management Studies, Vol. 50 No. 6, pp. 1041-1069.

Zhang, J. and Liu, P. (2012), "Rational herding in microloan markets", Management Science, Vol. 58 No. 5 , pp. 892-912.

Perceptions in reward-based crowdfunding

Zhao, H., Seibert, S.E. and Lumpkin, G.T. (2010), "The relationship of personality to entrepreneurial intentions and performance: a meta-analytic review", Journal of Management, Vol. 36 No. 2, pp. 381-404.

Zheng, H., Wan, N., Chen, D. and Wang, T. (2014), “Antecedents of project implementation success in crowdfunding”, PACIS 2014 Proceedings, Vol. 318, available at: https://aisel.aisnet.org/cgi/ viewcontent . cgi? article $=1069$ andcontext $=$ pacis2014 (accessed 9 August 2019).

\section{Corresponding author}

Anthony Macari can be contacted at: macaria@sacredheart.edu

For instructions on how to order reprints of this article, please visit our website:

www.emeraldgrouppublishing.com/licensing/reprints.htm

Or contact us for further details: permissions@emeraldinsight.com 